\title{
Characterization of Soils of Lower Dibang Valley District of Arunachal Pradesh, North East India
}

\author{
Sangey Chom Thungon ${ }^{1}$, T.J. Ramesha ${ }^{2}$ and Channakeshava ${ }^{3 *}$
}

${ }^{1}$ Krishi Vigyan Kendra, Lower Dibang Valley District, Arunachal Pradesh, India

${ }^{2}$ Soil Science and Agriculture Chemistry, Agriculture College, Hassan, Karnataka, India

\author{
*Corresponding author
}

\begin{tabular}{|c|}
\hline Keywords \\
\hline $\begin{array}{l}\text { Organic Carbon } \\
\text { values, nitrogen } \\
\text { status, P, Iron, } \\
\text { Manganese content }\end{array}$ \\
\hline Article Info \\
\hline $\begin{array}{l}\text { Accepted: } \\
\text { 20 June } 2018 \\
\text { Available Online: } \\
\text { 10 July } 2018\end{array}$ \\
\hline
\end{tabular}

A field study on Characterization of soils of Lower Dibang Valley District of Arunachal Pradesh, North East India was carried out at Krishi Vigyan Kendra, Lower Dibang Valley district of Arunachal Pradesh North East India during 2017-18. The soil properties of different villages revealed that the soil reaction $(\mathrm{pH})$ ranges from 4.3 to 5.3 . The lowest soil $\mathrm{pH}$ was recorded in Rayang village and the higher $\mathrm{pH}$ value of 5.3 recorded in Kangkog, Balek and Rukmo villages. Organic Carbon values ranged from 0.80-2.00 and are categorized as medium to high in range. The soluble salt content of soil measured in terms of electrical conductivity of soil solution $(\mathrm{dS} / \mathrm{m})$ which recorded as normal in range in all the soils of the villages $(0.02$ to $0.3 \mathrm{dS} / \mathrm{m}$ ). The soils of different villages, 23.0 percent of soil samples belongs to low category with respect to available nitrogen status and 40 percent of soil samples fall in the category medium and high. The available nitrogen content ranges from 118.7 to $366.5 \mathrm{~kg} / \mathrm{ha}$ ). The available P content of soil ranges from 20.7 to $94.73 \mathrm{~kg} / \mathrm{ha}$. However higher $\mathrm{P}$ content was recorded in Jia village and lowest $\mathrm{P}$ content recorded in Rumo village. Higher $\mathrm{P}$ content in soil was due to higher organic carbon content of soil where $\mathrm{P}$ fixation in soil reduced and which resulted in more availability of $\mathrm{P}$ in soil. In general 61.3 percent soils are high in $\mathrm{K}$ status and 38.46 percent soils belongs to medium in range of $\mathrm{K}$ in soils. However, none of the soils fall under category of low K status in soil. The maximum Sulphur content was recorded in Horupahar village which recorded highest of $65 \mathrm{~kg} / \mathrm{ha}$ (high in rage).Sulphur content ranges from 14.0 to $65.0 \mathrm{~kg} / \mathrm{ha}$. As regard to micronutrient status of soil, the available zinc content of soil ranges from 0.18 to $2.74 \mathrm{ppm}$. In general 23.0 percent of soils belongs to high Zinc content of soil and 10.0percent of soils categorized as low in Zinc status and 20 percent of soils belongs to medium in Zinc status. The available boron content of soil ranges from 0.18 to $6.53 \mathrm{ppm}$ among the soils of different villages. However the 69 percent of soils fall in the category of higher boron content, 23 percent soils belongs to medium in boron content and 15 percent soils having low boron content in soils. The Manganese content in soil ranges from 0.45 to $19.5 \mathrm{ppm}$ across the villages of lower Debang Valley. However higher manganese content of soil recorded in Kebali, Balek, Jia, Iduli, Horupahar, Bolung, Koronu and Meka and cover 53.84 percent of soils of different villages. Iron content of soil ranges from 21.0 to $106 \mathrm{ppm}$ and all the soils belongs to higher range of iron status in soil. The available copper content of soil ranges from 0.37 to $4.09 \mathrm{ppm}$ among the soils at different locations. 


\section{Introduction}

Soil is a natural body with the existence of human beings is closely related. It is the mantle on the land surface that acts as the medium for plant growth. Organic farming is primarily in operation in areas under shifting cultivation and traditional land use systems in north east India. Nearly $57.1 \%$ of total geographical area in India is under the threat of land degradation mainly by water erosion. On an average $37.1 \%$ of total geographical area in North East India is in degraded state. The fertiliser use in most of the state of region is far below national average.

North East India is becoming increasingly deforested and its crop productivity is declining primarily due to shortening of jhum cycles. Natural as well as anthropogenic activities have rendered natural resources viz., soil, water and forests vulnerable to such extent that river flow during monsoon season causes slides and erosion and during dry season, the problems of water shortage is ensured. However non forest activities are expanding rapidly worldwide at the expense of natural forests and at a pace which is much faster in environmental fragile hilly tract Globally, agricultural expansion and infrastructural development contributes $37 \%$ of forest degradation, responsible for $1 / 3^{\text {rd }}$ of tropical deforestation. Arunachal Pradesh is the land of raising sun comprises of mountainous and sub-mountainous portions of Himalayan systems in its extremity, covering an area of 83743 sq.kms.

In this contest it is an obligatory to characterize soils of Lower Dibang Valley District region for identification of production constraints related to soil chemical properties including nutrient status of soils for finding suitable solutions and also to overcome problems of ecological imbalance to achieve sustainability of the existing ecosystem in the region.

\section{Materials and Methods}

\section{Study site}

Lower Dibang Valley District, is the 15th district of Arunachal Pradesh is located in the Eastern part of Arunachal Pradesh.. The Lower Dibang Valley named after River Dibang, one of the tributaries of mighty River Brahmaputra, which flows in the district. The district has three sub-division viz. Roing, Dambuk and Hunli and 6 (six) administrative circles namely, Hunli, Desali, Dambuk, Paglam, Koronu and Roing

The district is bounded on the North by Dibang Valley District and China, on the East Lohit District, and on the west East Siang and Upper Siang District of Arunachal Pradesh and on the south Sadiya Sub-division of Tinsukia district, Assam state. It covers an area of 3900 Sq.Kms with a population of 53985 (As per 2015 census), altitude is 390 mtrs and relative humidity (62.92-90.36 (Source: KVK Annual Report-2016-17). It lies between $27^{0}-30^{\prime} \mathrm{N}$ to $28^{\circ}-33^{\prime} \mathrm{N}$ lattitude, $95^{\circ}$ $-15^{\prime} \mathrm{E}$ to $96^{0}-30^{\prime} \mathrm{E}$ longitude.

The district possess good climatic condition with agroclimatic zones like Sub - tropical Plain Zone characterized by hot summer and moderately cool winter with mean annual rainfall varies from 2590 - 3390mmand Mid tropical Hill Zone characterised by mild summer and moderate to severe winter. The mean annual rainfall ranges between 2000 to $5000 \mathrm{~mm}$. Also soil types of undulating upland of 4715 ha area characterised with soils are strongly to moderately acidic in nature ( $\mathrm{pH} 4.5$ to 7.2), Soils of gentle slopes of 11779 ha area characterised by Deep, well to imperfectly drained, fine/ fine loamy/ coarse loamy or coarse silty with moderate erosion and slight to moderate flood hazard. Soils of level to nearly level flood plain of 7073 ha area characterised by Deep, well to 
moderately well drained, coarse loamy to coarse silty with moderate flood hazard. Soils on channel bars are moderately shallow, excessively drained and sandy in texture.

\section{Soil sampling and laboratory analysis}

During the year 2015-16,soil samples were collected (using a steel corer, $5 \mathrm{~cm}$ inner diameter) from four adopted villages namely Kangkong, Jia, Rukmo, Kebali and Balek under the Mera Gaon Mera Gaurav, while, during the year 2017-18, soil sample collected from Rukmo, simari, Horupahar, Rayang, Denlo, Koronu, Bhismaknagar, Meka, Bolung and Iduli villages.

Samples were brought to the laboratory to analyze their physico-chemical characteristics. Soil samples were air-dried, grinded and sieved $(<150 \mathrm{~mm})$ prior to the samples used for physico-chemical analysis. The collected samples were analysed using MRIDAPARIKSHAK-A minilab for soil analysis and fertiliser advisory developed by ICAR-Indian institute of Soil Science, Bhopal for major nutrients like available Nitrogen, Phosphorous and Potassium and minor nutrients like copper, manganese, iron, zinc, boron, sulphur, $\mathrm{pH}$, and $\mathrm{EC}$ and organic carbon. After the analysis of soils, the soil Health cards distributed to farmers during world soil day programme to create awareness among farming community about soil health and its importance.

\section{Results and Discussion}

The results with respect to soil properties like $\mathrm{pH}$, Ec, Organic carbon, available nitrogen, phosphorus, Potassium Sulphur, zinc, boron, iron, Manganese and copper at different villages have been presented in table 1 and each parameters discussed in paragraph as below.

\section{Soil reaction $(\mathrm{pH})$}

Results revealed that soil reaction of soils of different villages of lower Dibang valley district ranges from 4.3 to 5.3. The lowest soil $\mathrm{pH}$ was recorded in Rayang village and the higher $\mathrm{pH}$ value of 5.3 recorded in Kangkog,Balek and Rukmo villages. The Low soil $\mathrm{pH}$ was associated to the leaching of basic cations ( $\mathrm{Ca}, \mathrm{Mg}$ and $\mathrm{K}$ ) due to heavy rain during the monsoon season which resulted in retention of hydrogen, iron and aluminium ions with strong binding force with charged soil particles thereby increases soil acidity. Soil acidification often leads severe problems to the maintenance of slash-and-burn agricultural fields in humid tropics area.

\section{Organic carbon $(\%)$}

Organic Carbon values ranged from 0.802.00. Different agricultural practices decrease the soil organic matter with stored carbon in soils as well as global carbon balance (Sellers et al., 1997, Lal 2001; Santra 2012). Soil carbon and nitrogen losses are associated with decreased plant organic matter inputs and high decomposition rate and erosion which are mainly associated with agricultural lands. Soil organic carbon ranged between $0.59 \%$ and $2.38 \%$ in the present study, which is higher than the values $(0.8-1.24 \%)$ reported by Manuwa (2009) and $1.42-1.74 \%$ by Arunachalam (2002) from the Jhum lands in north east India

\section{Soluble salt content of soil (dS/m)}

The soluble salt content of soil measured in terms of electrical conductivity of soil solution $(\mathrm{dS} / \mathrm{m})$ which recorded as normal in range in all the soils of the villages ( 0.02 to $0.3 \mathrm{dS} / \mathrm{m})$. The lower soluble salt content of soil was recorded in Koronu soils and higher salt content recorded in Kebali soils. Lower salt content was attributed to leaching of salts due 
to higher rainfall and higher permeability of soils for flow of salts to lower soil depth as the retention of salts decreased due to low clay and organic matter content of surface soils.

\section{Available Nitrogen content in soil (kg/ha)}

Among the soils of different villages 23.0 percent of soil samples belongs to low category with respect to available nitrogen status and 40 percent of soil samples fall in the category medium and high in nitrogen status of soil. The available nitrogen content ranges from 118.7 to $366.5 \mathrm{~kg} / \mathrm{ha}$ ). The higher available nitrogen content of soil was recorded in the villages of Koronu $366.5 \mathrm{~kg} / \mathrm{ha}$ ), Meka $315.7 \mathrm{~kg} / \mathrm{ha}$ ) and Reyang (366.5 kg/ha) was attributed to continuous application of nitrogen fertilizer under intensive cultivation practices in the location. These results were in agreement with findings of Bhuyan (2001).

\section{Available P content of Soil (kg/ha)}

The available $\mathrm{P}$ content of soil ranges from 20.7 to $94.73 \mathrm{~kg} / \mathrm{ha}$. However higher P content was recorded in Jia villageand lowest $P$ content recorded in Rumo village. Higher $\mathrm{P}$ content in soil was due to higher organic carbon content of soil where $\mathrm{P}$ fixation in soil reduced and which resulted in more availability of $\mathrm{P}$ in soil. Application of lime to acid soils during cultivation of crops can also increases availability of $\mathrm{P}$ in soil than at low $\mathrm{pH}$ soil without lime application (Ghosh etal,1980). Addition of lime decreases activity of $\mathrm{Fe}$ and $\mathrm{Al}$ in soil thus reduces $\mathrm{P}$ fixation in soil.

\section{Available $\mathrm{K}$ content in soil ( $\mathrm{kg} / \mathrm{ha})$}

The available $\mathrm{K}$ content of soil generally increased due to application of $\mathrm{K}$ to soil during cultivation practices and also accumulation of $1: 1$ and 2:1 type of clay minerals which contribute for accumulation of
$\mathrm{K}$ in soil. In general61.3 percent soils are high in $\mathrm{K}$ status and 38.46 percent soils belongs to medium in range of $\mathrm{K}$ in soils. However, none of the soils fall under category of low $\mathrm{K}$ status in soil (Bhuyan, 2001). The higher $\mathrm{K}$ content of $431.2 \mathrm{~kg} / \mathrm{ha}$ recorded Meka location and lowest $\mathrm{K}$ was recorded in Jia village (133.0 $\mathrm{kg} / \mathrm{ha}$ ).

\section{Available $\mathrm{S}$ content of soil ( $\mathrm{kg} / \mathrm{ha})$}

The sulphur content of soil was higher in soils of Horupahar, Kebali, Kengkong Balek, Simari,and Meka villages which categorized as medium in range followed by Jia, Koronu and Rayang villages which contain low in range. The maximum Sulphur content was recorded in Horupahar village which recorded highest of $65 \mathrm{~kg} / \mathrm{ha}$ (high in rage). The higher $S$ content was attributed to adsorption of sulphur on soil exchange surface of 1:1 and 2:1 type of clay minerals through clay humus complexes which retain more sulphur in soil. However, desorption and leaching of sulphur takes place where organic carbon and clay content in soil decreased (Hudson, 1963). Addition of $\mathrm{S}$ as fertilizer in the production practices of field crops in the villages also contributed for higher S status of soil.

\section{Micronutrient status of soil (Table 2)}

\section{Available Zinc (ppm)}

Among the villages, the available zinc content of soil ranges from 0.18 to $2.74 \mathrm{ppm}$. In general 23.0 percent of soils belongs to high Zinc content of soil and 10.0percent of soils categorized as low in Zinc status and 20 percent of soils belongs to medium in Zinc status. The higher zinc status of soil was attributed to higher accumulation of organic matter in soil and also retention of zinc in chelated form with organic constituents in soil. 
Table.1 Weather data

\begin{tabular}{|c|c|c|c|c|}
\hline Month & Rainfall (mm) & & & Relative Humidity (\%) \\
\hline & & Maximum & Minimum & \\
\hline April & 1279.38 & 24 & 19.86 & 90.36 \\
\hline May & 2331.07 & 28.33 & 24.16 & 85.58 \\
\hline June & 3199.85 & 30.53 & 25.36 & 86.73 \\
\hline July & 4720.81 & 29.22 & 24.74 & 86.70 \\
\hline August & 6354.96 & 33.25 & 27.38 & 85.58 \\
\hline September & 6939.20 & 28.03 & 24.36 & 81.76 \\
\hline October & 2235.68 & 29.67 & 21.51 & 76.41 \\
\hline November & 1033.67 & 26.33 & 17.80 & 63.83 \\
\hline December & 1038.56 & 23.03 & 15.41 & 64.90 \\
\hline January & - & 21.58 & 14.03 & 64.25 \\
\hline February & 66.96 & 23.96 & 15.85 & 62.92 \\
\hline March & 237.45 & 23.06 & 16.58 & 69.54 \\
\hline
\end{tabular}

Table.2 Soil samples analysed for various parameters

\begin{tabular}{|l|l|l|l|l|l|l|l|l|l|l|l|l|}
\hline Village & $\mathrm{pH}$ & $\begin{array}{l}\mathrm{EC} \\
(\mathrm{dS} / \mathrm{m})\end{array}$ & $\begin{array}{l}\mathrm{OC} \\
(\%)\end{array}$ & $\begin{array}{l}\mathrm{N} \\
\mathrm{Kg} / \mathrm{ha}\end{array}$ & $\begin{array}{l}\mathrm{P}_{2} \mathrm{O}_{5} \\
\mathrm{Kg} / \mathrm{ha}\end{array}$ & $\begin{array}{l}\mathrm{K} / \mathrm{O} \\
\mathrm{Kg} / \mathrm{ha}\end{array}$ & $\begin{array}{l}\mathrm{S} \\
\mathrm{Kg} / \mathrm{ha}\end{array}$ & $\begin{array}{l}\mathrm{Zn} \\
\mathrm{ppm}\end{array}$ & $\begin{array}{l}\mathrm{B} \\
\mathrm{ppm}\end{array}$ & $\begin{array}{l}\mathrm{Fe} \\
\mathrm{ppm}\end{array}$ & $\begin{array}{l}\mathrm{Mn} \\
\mathrm{ppm}\end{array}$ & $\begin{array}{l}\mathrm{Cu} \\
\mathrm{ppm}\end{array}$ \\
\hline Kebali & 5.2 & 0.26 & 1.67 & 265.53 & 25.8 & 198.6 & 24.96 & 2.74 & 5.59 & 56.33 & 2.12 & 0.6 \\
\hline Kangkong & 5.3 & 0.09 & 0.91 & 170.97 & 21.58 & 178.51 & 24.88 & 1.92 & 2.00 & 38.10 & 1.72 & 0.83 \\
\hline Balek & 5.3 & 0.16 & 0.99 & 215.33 & 24.63 & 261.4 & 22.56 & 2.31 & 2.11 & 106.1 & 2.82 & 1.67 \\
\hline Rukmo & 5.3 & 0.3 & 0.80 & 165.6 & 20.7 & 176.14 & 24.14 & 1.80 & 2.99 & 61.12 & 1.85 & 0.72 \\
\hline Jia & 4.7 & 0.07 & 1.27 & 299.8 & 94.73 & 133.1 & 14 & 1.0 & 2.02 & 27 & 2.25 & 0.37 \\
\hline Iduli & 5.0 & 0.23 & 1.92 & 291.9 & 70.60 & 374.0 & 31.0 & 0.18 & 1.28 & 36.7 & 19.3 & 2.43 \\
\hline Horupahar & 4.9 & 0.07 & 2.00 & 118.7 & 25.91 & 379.2 & 65 & 10.7 & 0.18 & 13.0 & 4.45 & 4.09 \\
\hline Bhismaknagar & 4.7 & 0.13 & 1.00 & 261.6 & 25.02 & 249.2 & 29 & 0.18 & 1.28 & 36.7 & 1.93 & 2.43 \\
\hline Bolung & 5.2 & 0.04 & 1.07 & 271.2 & 32.17 & 306.5 & 34 & 1.6 & 6.53 & 21.0 & 4.7 & 0.46 \\
\hline Koronu & 5.2 & 0.02 & 1.74 & 366.5 & 40 & 338 & 15.00 & 0.17 & 2.2 & 31.3 & 4.0 & 1.1 \\
\hline Simari & 4.5 & 0.11 & 1.74 & 166.3 & 43.79 & 185 & 29 & 1.62 & 0.9 & 33 & 0.45 & 1.52 \\
\hline Meka & 4.4 & 0.22 & 1.59 & 315.7 & 39.92 & 431.2 & 22.00 & 2.22 & 5.18 & 25.1 & 2.69 & 1.93 \\
\hline Rayang & 4.3 & 0.16 & 1.16 & 366.5 & 28.70 & 253.5 & 16.9 & 0.89 & 2.20 & 22.8 & 1.35 & 0.90 \\
\hline
\end{tabular}




\section{Available Boron in soil (ppm)}

The available boron content of soil ranges from 0.18 to $6.53 \mathrm{ppm}$ among the soils of different villages. However the 69 percent of soils fall in the category of higher boron content, 23 percent soils belongs to medium in boron content and 15 percent soils having low boron content in soils. The higher and medium boron content of soils may be due to application of boron fertilizer to crops grown in the area in the intensive cropping system. Lower boron content in soils was due to fixation of Boron with $\mathrm{Fe}$ and $\mathrm{Al}$ which are predominant in soil and resulted in low availability of boron in soil (Nayak et al., 2000).

\section{Available Manganese content in soil. (ppm)}

The Manganese content in soil ranges from 0.45 to $19.5 \mathrm{ppm}$ across the villages of lower Debang Valley. However higher manganese content of soil recorded in Kebali, Balek,Jia, Iduli, Horupahar, Bolung, Koronu and Meka and cover 53.84 percent of soils of different villages. Among the soils of different villages 38.46 percent soils having medium in range with respect to Manganese content of soil. Higher Manganese content of soils due to presence of dominant ferro magnesiun minerals (Magnetite) and parent material which contains higher manganese content from which soil formed (Gupta et al., 2000).

\section{Available iron content in soil (ppm)}

It is interesting to note that all the soils at different villages contains higher iron content in soil and classified as higher in range. The higher Iron content may be due to predominance of iron bearing minerals such as Haematite and Magnetite and clay minerals like chlorite and vermiculite. Availability of iron in ferrous form is more in soil upon submergence during cultivation of crops like rice sometimes resulted in toxicity to the crops which can be managed through application of lime. Under climatic conditions of warm and humid condition due to intensive and deep weathering leaching of silica leaving behind iron and alumina contributed for higher iron content in soil (Gupta et al., 2000).

\section{Available copper content in soil (ppm)}

The available copper content of soil ranges from 0.37 to $4.09 \mathrm{ppm}$ among the soils at different locations. The higher copper content recorded in soils of Balek, Iduli, Horapuhar, Bhismaknagar and Meka villages. In rest of the villages the copper content recorded as low and medium in range. The higher copper content in soils was attributed to application of Copper based fungicides and also due to presence of copper bearing minerals such as chalcopyrites which contribute higher Copper content of soils (Nayak et al., 2000).

\section{Acknowledgement}

The main author is thankful to the Senior Scientist and Head for providing facilities to carry out the soil sampling and analysis work and bring out this research paper.

\section{References}

Arunachalam, A., (2002), Dynamics of soil nutrients and microbial biomass during first year cropping in an 8-year jhum cycle. Nutrient Cycling in Agroecosystems, 64, pp 283-291.

Bhuyan SI.2001. Soil nutrients status in prominent agro-ecosystems of East Siang district, Arunachal Pradesh. International Journal of Environmental Sciences. 2013; 3(6).

Das, D.K. 2003. Micronutrients: Their Behavior in Soils and Plants, Kalyani Publishers, New Delhi, pp.148-149. 
Hodgson, J.F. (1963). Chemistry of micronutrient elements in soils. Advances In Agronomy. 15: 69-94.

Ghosh, A.B. and R. Hasan.1980. Soil Fertility Map of India, Indian Agricultural Research Institute, New Delhi.

Gupta,G.P., Khamparia, R.S., Sharma, B.L. and Y.M. Sharma (2000). Extractable micronutrients in relation to properties of some red and yellow soils of Madhya Pradesh. Ann.agric.Res.21(4): $522-526$

Lal, R., (2001), Potential of desertification control to sequester carbon and mitigate the greenhouse effect, Climate change, 51, pp 35-72.23

Lal, R., (2001), Potential of desertification control to sequester carbon and mitigate the greenhouse effect, Climate change, 51, pp 35-72.23

Manuwa, S.I., (2009), Physico-chemical and dynamic properties of termite mound soil Relevant in sustainable food production, African crop science conference proceedings, 9, pp 365369.
Mete, P.K. and A. Samanta (1996). Distribution of iron fractions in red and lateritic soils of West Bengal. $J$. Maharashtra Agric. Univ.,21(3):327329.

Nayak, D.C., Mukhopadhyay and D. Sarkar (2000). Distribution of some available nutrients in alluvial soil of Arunachal Pradesh in relation to soil characteristics. Indian J. Soc. Soil Sci., 48(3): 612-614

Santra, P., Kumawat, R.N., Mertia, R.S., Mahla, H.R. and Sinha, N.K., (2012), Spatial variation of soil organic carbon stock in a typical agricultural farm of hot arid ecosystem of India, Current science, 102, pp 1303-1309

Sellers, P. J., Dickinson, R.E., Randall, D.A., Betts, A.K., Hall, F.G., Berry, J.A., Collatz, G.J., Denning, A.S., Mooney, H.A., Nobre, C.A., Sato, N., Field, C.B., Sellers, A.H., (1997), Modeling the exchanges of energy, water, and carbon between continents and the atmosphere, Science, 275(5299), pp 502-509.

\section{How to cite this article:}

Sangey Chom Thungon, T.J. Ramesha and Channakeshava. 2018. Characterization of Soils of Lower Dibang Valley District of Arunachal Pradesh, North East India. Int.J.Curr.Microbiol.App.Sci. 7(07): 2858-2864. doi: https://doi.org/10.20546/ijcmas.2018.707.335 